\title{
RELIABILITY AND VALIDITY OF THE MALAY VERSION OF MINDFUL ORGANIZING SCALE AMONGST NURSING STAFF
}

\author{
Muhammad Shoaib Saleem', Ahmad Shahrul Nizam Ishal, Yuzana Mohd Yusop², Maheen \\ labal Awan'
}

1. Universiti Teknologi PETRONAS, Maylasia

2. Universiti Sultan Zainal Abdin, Malaysia

Correspondence: sh.saleem87@gmail.com

\begin{abstract}
AIM:

This study tested the reliability and validity of the 9-item Mindful organizing scale and safety performance scale in the sample of private hospital nurses in different states of Malaysia.

METHODS:

Mindful Organizing scale and safety behavior scale were translated into Bahasa Malaya. To accomplish this task, the survey was conducted of 475 registered nursing staff in different states of Malaysia in 2020 through a self-administered questionnaire. For convergent and discriminant validity of our research variables, we used the Structural equation modeling (SEM) technique with the help of SPSS AMOS 21. A confirmatory factor analysis (CFA), reliability analysis, and analysis of aggregation through intra-class correlation coefficients indices were also carried out.
\end{abstract}

RESULTS:

Our results testified the unidimensional structure of the mindful organizing scale as well as for safety performance both indicators and exhibited satisfactory internal consistency for both mindful organizing and safety performance. Also, the aggregation of scores to the team level was well under the prescribed limit.

CONCLUSIONS:

We are confident to establish that the Malay version of the mindful organizing and safety performance scales has shown to be a reliable and valid measure that can measure collective mindfulness and safety behavior amongst nursing staff. Our translated version can be used in other high-reliability organizations (HROs) in this cultural context and other industries that also want to achieve reliability in their operational performance.

\section{KEYWORDS}

Mindful Organizing, Collective mindfulness, Safety performance, Scale validation, Nursing Staff.

\section{INTRODUCTION}

All firms, but especially those in the healthcare field, should pay close attention to the safety and wellness of their employees. There is a higher risk of occupational risks being encountered by healthcare workers, such as chemicals and blood-borne diseases as well as psychological and biological dangers as well as other anomalies in ergonomics when executing jobs. Because of this, 
workplace health and safety are a worldwide issue. There were 548,100 reported injury cases in 2017, according to the U.S. Department of Labor. [1,2]

Nurses had the greatest incidence rate at 10.9 per 100 fulltime employees since it is one of the most important aspects in healthcare. [1] An annual statistical review from the Social Security Organization (SOCSO) Malaysia confirms that the healthcare industry in Malaysia had 1549 occurrences last year, which is relevant to the issue at hand. There have also been 1365 cases of temporary impairments, 463 cases of permanent disabilities, and 20 cases of death overall. To add insult to injury, a total of 1344 people were exposed to hazardous chemical, physical and biological substances, [3] while 1350 people were affected by respiratory, skin, and musculoskeletal diseases/conditions [3] throughout different industrial sectors. These figures show that healthcare safety is also a concern. As a result, our study focuses on ways to improve workplace safety in the healthcare industry with the proposed benefits of mindful organizing (a collective and social construct) in connection with the safety behavior of employees in the Malaysian cultural context.

Mindful organizing was first conceptualized by Karl E. Weick [4] while evaluating the ability of high-reliability organizations e.g. (nuclear power plants, air traffic control, and military establishments) as to how they operate much safer over longer periods despite the inheritance of the catastrophic danger in their operations. Mindful organizing is the collective ability of the workforce to foresee and detect anomalies with enough details and act swiftly. $[5,6]$ Mindful organizing is a social process in high-reliability organizations (HROs), where employees forestall, detect, and even recoup from those anomalies. [4] The sensitivity of such organizations (HROs) can be witnessed through the fact that a tiny mistake can be the reason between life and death.

As a rule, safety behavior refers to the actions that employees do to comply with and adhere to specified safety requirements. [7,8] Many writers have defined two aspects of safety performance: safety compliance and safety participation. [7,9] This is in keeping with the past research and keeping in mind the distinction between task and contextual performance. Performing work while following specified safety standards, protocols, and procedures [7] constitutes safety compliance. Compliance with organizational rules also includes following SOPs, wearing personal protective equipment, and attending training sessions as well as following particular procedures in certain situations. To put it another way, safety behaviors that require official enforcement and acknowledgment fall under the category of safety compliance. [7] As a second point, safety participation is more of an extra-role behavior, in which an employee supports overall safety procedures, systems, and regulations by voluntary engagement. [7] As a consequence of intrinsic motivation and self-initiated activities, employees' contributions to overall safety performance in a company are most typically unrelated to official recognition or awards. [9] Such actions might include speaking out for safety in meetings, expressing concern for safety while performing tasks, and urging others to learn about safety, as well as supporting the general safety policy of the organization [9] are all instances of safety participation. As a result of current healthcare procedures, prescription, diagnosis, and treatment are more focused on patient safety [10] rather than on variables that may affect staff safety performance. As part of our research, we will add knowledge to the predictability variable for healthcare workers' safety behavior in order to overcome this literature bias.

In general, research on mindful organizing has prospered, but the Healthcare sector is the one that has witnessed true benefits of mindful organizing practice e.g., reduced accidents and enhanced safety performance of the sector in which mindful is practiced. [1 1] Amongst the nursing staff, groups that practiced mindful organizing had lesser occupational safety errors and omissions. [12,13] Prior literature also stated that mindful organizing has a positive impact on firefighters' safety performance as well as air traffic controllers. [4, 14] Quantitative evidence for mindful organizing research is still not abundant as this construct is still in its infancy phase. [15] There is an emerging need for more empirical evidence of the mindful organizing construct for establishing its strong and distinct theoretical standing amongst different team-level constructs. [1 1]

To extend the empirical evidence of mindful organizing an assessment and validation of this scale would be of great help for organizations to opt for mindful organizing. In past literature, certain pieces of evidence tried to validate mindful organizing measures in different contexts, but end up with insufficient psychometric properties of their scales . [11] There are few different versions of the mindful organizing scale in languages like Spanish, [15] English, [16] French, German and Italian, [12] but no Malay version of mindful organizing exists in the literature. English version of mindful organizing scale has already been tested in 
hospital settings. [16] Mindful organizing concerning safety was observed in the healthcare sector especially in hospitals and care centers. As expected, quantitative evidence is also very limited in this domain. $[7,18]$ According to the findings of one research, [17] variables like reliability enhancing work practices (REWPs), respectful interactions, affective commitment, organizational citizenship behavior, and mindful organizing were positively related to patient safety and medication errors.

Aforesaid does not solely imply that Malay-speaking organizations in more than 07 countries including Malaysia, Indonesia, Brunei, Singapore, East Timor, and Christmas island, etc., where the Malay language is native, as well as official, do not possess a validated mindful organizing scale to be utilized in empirical researches, but it also provides us the opportunity to see the manifestation of mindful organizing in the Malaysian cultural context as it has been studied or practices in first world countries i.e. the USA. In past literature, validation of mindful organizing scale is performed mainly in high-reliability organizations (HROs), where validation of mindful organizing will be valuable in non-traditional HRO context as to how mindful organizing embodiment can be observed in this sector.

In doing so, to specify the objectivity of this study, firstly, we will translate the English version of the "mindful organizing [19]" scale as well as its antecedent i.e., safety behavior scale $[9,20]$ to the Malay language, and validate their new version in the Malaysian cultural context. Secondly, we will be assessing the convergent and discriminant validity for both scales. By doing so, we will provide empirical evidence through the validity and reliability of the Malay version of the scale by testing its unidimensional structure as well as its internal consistency. Further, we will also try to justify the aggregation of responses to a group level to see if there is a consensus amongst team members for mindful organizing.

\section{METHODS}

\section{TRANSLATION OF SCALE}

We followed the translation established in the guideline. [21] Primarily, two individual translators (freelancers and also a member of local linguistic society) translated the English version of the safety organizing scale and safety behavior scale into the Malay language. We then compared both translated versions and discussed them with the translators leading to the production of the final scale. Further, with the help of two professionals (bilingual persons), one holding a doctoral degree and one holding a master's degree translated back the scale into the English version. Later, both the original English version of the "safety organizing scale and safety behavior scale" as well as the reverse-translated versions scales were compared and some of the minor corrections were made accordingly. This initial version of the mindful organizing scale went through a pilot study with 40 participants working in different hospitals. All of the respondents well-understood the questionnaire and no difficulty was faced by them. However, two of the respondents recommended few words be replaced for better comprehension.

\section{PARTICIPANTS AND DATA COLLECTION}

This research was done in accordance with the American Psychological Association's worldwide criteria (APA). For this study, we collected data from nursing staff from ten private hospitals located in different states of peninsular Malaysia (northern, western, eastern, and central regions). Participation was voluntary and participants were ensured about the anonymity and confidentiality of their responses. Participants were provided with a consent form before filling the questionnaire. Moreover, there were no educational tests (cognitive, diagnostic, or aptitude) used in our study. Instead, we used a cross-sectional questionnaire, which did not require any procedures or observation of public (respondents') behavior, and did not collect any identifiable private information, so no ethical review was required. Further, our research does not cause any foreseeable risk or harm to participants at any level. A convenience sampling technique was used, where nursing staff who is permanently employees in private hospitals were invited to participate in the study. Data collection was conducted in accordance with all ethical principles and norms. The data was collected in the year 2020. The sample in the present study comprises 475 workers from 53 different teams working in different hospitals with an average team size of 9 individuals. Overall, 590 questionnaires were disbursed, where after an initial assessment of the responses, few of the questionnaires were excluded because of the reason like missing values, unclear responses. The final response rate for this study was $80.5 \%$ $(n=475 / 590)$. For this study, a team is defined as if two or more individuals working toward a mutual objective (22). Demographic information of the respondents is shown in Table.01 


\begin{tabular}{|l|l|l|}
\hline CATEGORY & SUB-CATEGORY & NUMBERS \\
\hline \multirow{4}{*}{ Gender } & Female & 340 \\
\cline { 2 - 3 } & Male & 135 \\
\hline \multirow{4}{*}{ Work Experience } & $18-25$ & 89 \\
\cline { 2 - 3 } & $26-35$ & 162 \\
\cline { 2 - 3 } & $36-45$ & 179 \\
\cline { 2 - 3 } & 45 \& Above & 45 \\
\hline \multirow{4}{*}{ Education } & $<5$ Year & 55 \\
\cline { 2 - 3 } & $6-10$ Years & 117 \\
\cline { 2 - 3 } & $11-15$ Years & 221 \\
\cline { 2 - 3 } & 20 \& Above Years & 82 \\
\hline \multirow{4}{*}{$\begin{array}{l}\text { Number of the hospitals } \\
\text { different states }\end{array}$} & "Foundation, Diploma" & 189 \\
\cline { 2 - 3 } & "Bachelor's Degree" & 199 \\
\cline { 2 - 3 } & "Master's Degree" & 87 \\
\cline { 2 - 3 } & Perak & 02 \\
\cline { 2 - 3 } & Kelantan & 02 \\
\cline { 2 - 3 } & Negeri Sembilan & 02 \\
\cline { 2 - 3 } & Penang & 01 \\
\cline { 2 - 3 } & Selangor & 01 \\
\hline
\end{tabular}

\section{MEASURES}

\subsection{Mindful Organizing}

The original scale of Mindful organizing developed by Weick and Sutcliffe and Timothy Vogus was translated from English to the Malay language $(16,19)$. This scale is unidimensional in its structure and is comprised of a total of nine items. This scale helps researchers to see the extent to which groups and the team pay attention to the forthcoming issue/anomalies and act accordingly to overcome them $(4,5)$. To gauge their team's efforts, respondents used a 5-point Likert scale ranging from 1 (strongly disagree) to 5 (strongly agree). An example item is "When discussing emerging problems with coworkers, we usually discuss what to look out for". A complete set of the original and translated version is available at Exhibit-A at the end of this research paper.

\subsection{Safety Behavior}

Safety behavior was assessed using one of the renowned instruments developed by Neal \& Griffin (9). This scale contains six items representing three items for "safety compliance" and three statements for "safety participation". Example statements for safety compliance are "I use all the necessary safety equipment to do my job," "I use the correct safety procedures for carrying out my job, "and "I ensure the highest levels of safety when I carry out my job", where statements for safety participation are "I promote the safety program within the organization", "I put in extra effort to improve the safety of the workplace" and "I voluntarily carry out tasks or activities that help to improve workplace safety".

\section{DATA ANALYSIS}

We used SPSS version 21 for descriptive and reliability statistics. Further SPSS AMOS 21 was used to test the internal factor structure, confirmatory factor analysis (CFA), convergent and discriminant validity of mindful organizing, and safety behavior scales. For convergent validity, standardized factor loading (SFL), composite factor loadings (CR), and average variance extracted (AVE) were utilized commonly used in prior researches (23-25). To test the model fit aspect we used goodness of fit indices i.e. CMIN (chi-square $X^{2}$ /degree of freedom), chi-square $X^{2}$, comparative fit index (CFI), root-mean-square error of approximate (RMSEA), normed fit index ( NFI), goodness-offit index (GFI), adjusted goodness-of-fit index (AGFI), Tacker-Lewis index (TLI) $(26,27)$. Further, the reliability of the 
mindful organizing and safety behavior scale was assessed via the Cronbach alpha coefficient. For mindful organizing, which is a team-level construct we used aggregation indices i.e. intraclass correlation ICC (K).[28]

\section{RESULTS}

\section{RELIABILITY AND VALIDITY ANALYSES}

To test the internal consistency of each construct of the questionnaire, a reliability test was performed. To achieve acceptable reliability in responses, the acceptable value of Cronbach's alpha is .70 (29). Through our findings, Cronbach's alpha values varied from 0.81 to 0.92 for all scales i.e. 0.92 for mindful organizing, 0.818 for safety compliance, and 0.813 for safety participation, indicating good reliability for all scales utilized. Findings in this study confirm the strong psychometric characteristics of our modified instruments, as well as their reliability or suitability for application in a given situation.

\section{CONVERGENT AND DISCRIMINANT VALIDITY}

There are common indicators like construct reliability (CR), standardized factor loadings (SFL), and average variance extracted (AVE) with the acceptance criteria of; SFL > 0.6, $\mathrm{CR}>0.7$, and $\mathrm{AVE}>0.5$, that are used to assess the convergent validity of the constructs. Convergent validity indicators are also shown in table-2 which reflects the suitable power of items in association with variables and all variables met those criteria demonstrating acceptable convergent validity. For discriminant validity, the square root of the average variance extracted (AVE) value was compared with the correlation coefficient of other variables (30). Whereas, if the outcome value is greater than its correlation coefficient, then the discriminant validity is achieved (table-02). All of the constructs met this criterion and are depicted in table-03.

\section{TABLE-02 RESULTS OF THE CONVERGENT VALIDITY TESTS}

\begin{tabular}{|c|c|c|c|c|c|c|c|}
\hline CONSTRUCTS & ITEMS & SFL & CR & AVE & $\mathbf{A}$ & MEAN & $\begin{array}{l}\text { STD. } \\
\text { DEVIATION }\end{array}$ \\
\hline \multirow{9}{*}{$\begin{array}{l}\text { Mindful } \\
\text { Organizing }\end{array}$} & Minf-Org-1 & 0.754 & \multirow{9}{*}{0.925} & \multirow{9}{*}{0.577} & \multirow{9}{*}{0.924} & 4.1453 & 1.36 \\
\hline & Minf-Org -2 & 0.73 & & & & 4.1684 & 1.37 \\
\hline & Minf-Org -3 & 0.745 & & & & 4.1389 & 1.38 \\
\hline & Minf-Org -4 & 0.796 & & & & 4.1326 & 1.36 \\
\hline & Minf-Org -5 & 0.759 & & & & 4.2105 & 1.36 \\
\hline & Minf-Org -6 & 0.805 & & & & 4.0926 & 1.37 \\
\hline & Minf-Org -7 & 0.769 & & & & 4.1958 & 1.34 \\
\hline & Minf-Org -8 & 0.761 & & & & 4.1579 & 1.35 \\
\hline & Minf-Org -9 & 0.716 & & & & 4.1537 & 1.37 \\
\hline \multirow{3}{*}{$\begin{array}{l}\text { Safety } \\
\text { Compliance }\end{array}$} & Saf-com-1 & 0.764 & \multirow{3}{*}{0.819} & \multirow{3}{*}{0.602} & \multirow{3}{*}{0.818} & 3.8126 & 1.37 \\
\hline & Saf-com -2 & 0.815 & & & & 3.8800 & 1.37 \\
\hline & Saf-com -3 & 0.746 & & & & 3.8000 & 1.40 \\
\hline \multirow{3}{*}{$\begin{array}{l}\text { Safety } \\
\text { Participation }\end{array}$} & Saf-part-1 & 0.795 & \multirow{3}{*}{0.814} & \multirow{3}{*}{0.593} & \multirow{3}{*}{0.813} & 3.8211 & 1.33 \\
\hline & Saf-part -2 & 0.762 & & & & 3.8400 & 1.32 \\
\hline & Saf-part -3 & 0.751 & & & & 3.7663 & 1.31 \\
\hline
\end{tabular}

TABLE-03 RESULTS OF THE DISCRIMINANT VALIDITY TESTS

\begin{tabular}{|l|l|l|l|l|l|l|}
\hline CONSTRUCTS & AVE & MSV & $\begin{array}{l}\text { MAXR } \\
(H)\end{array}$ & $\begin{array}{l}\text { MINDFUL } \\
\text { ORGANIZING }\end{array}$ & $\begin{array}{l}\text { SAFETY } \\
\text { COMPLIANCE }\end{array}$ & $\begin{array}{l}\text { SAFETY } \\
\text { PARTICIPATION }\end{array}$ \\
\hline Mindful Organizing & 0.58 & 0.036 & 0.926 & 0.76 & & \\
\hline Safety Compliance & 0.6 & 0.002 & 0.823 & -0.043 & 0.776 & \\
\hline Safety Participation & 0.59 & 0.036 & 0.815 & $0.191^{* * *}$ & -0.039 & 0.770 \\
\hline "Note: $* * *=0.001 "$ "
\end{tabular}




\section{MEASUREMENT MODEL}

To evaluate the measuring models for mindful organizing and safety behavior, indices such as CMIN (chi-square $\mathrm{X} 2$ /degree of freedom), chi-square $\mathrm{X} 2$, comparative fit index (CFI), root-mean-square error of approximate (RMSEA), normed fit index (NFI), goodness-of-fit index (GFI), adjusted goodness-of-fit index (AGFI), Tacker-Lewis index
(TLI) $(26,27)$ were utilized. Through aforesaid, the quality of two measurement models was confirmed, whereas, all of the values for each index were well under the criteria. To make the comprehension easy for the readers, table-04 represents the measurement models fit statistics against the confirmatory factor analysis (CFA), which shows that our results are acceptable and goodness of fit was achieved for mindful organizing and safety behavior.

TABLE-04 RESULTS OF THE FIT INDEXES FOR THE MEASUREMENT MODELS.

\begin{tabular}{|c|c|c|c|c|c|c|}
\hline \multirow{2}{*}{$\begin{array}{l}\text { CATEGORIES OF } \\
\text { STATISTICS }\end{array}$} & \multirow{2}{*}{ STATISTICS } & \multirow{2}{*}{$\begin{array}{l}\text { FITNESS } \\
\text { CRITERIA }\end{array}$} & \multicolumn{2}{|c|}{$\begin{array}{l}\text { MINDFUL } \\
\text { ORGANIZING }\end{array}$} & \multicolumn{2}{|c|}{ SAFETY BEHAVIOR } \\
\hline & & & VALUE & DECISION & VALUE & DECISION \\
\hline \multirow[t]{2}{*}{ Absolute fit indices } & RMSEA & $\begin{array}{l}<0.08 ;<0.05 \text { is } \\
\text { excellent and } \\
<0.08 \text { is good }\end{array}$ & .036 & Accept & .06 & Accept \\
\hline & GFI & $>0.90$ & .980 & Accept & .996 & Accept \\
\hline \multirow{4}{*}{ Incremental fix index } & AGFI & $>0.90$ & .967 & Accept & .988 & Accept \\
\hline & $\mathrm{NFI}$ & $>0.90$ & .983 & Accept & .994 & Accept \\
\hline & TLI & $>0.90$ & .991 & Accept & 1 & Accept \\
\hline & $\mathrm{CFI}$ & $>0.90$ & .993 & Accept & 1 & Accept \\
\hline Parsimonious fit indices & x2/DOF & $<2.00$ & 1.59 & Accept & .789 & Accept \\
\hline
\end{tabular}

\section{STRUCTURAL MODEL}

We tested the overall structural model with the SEM technique. To assess the Goodness-of-fit, we tested if the responses were fitting the measurement as well as a structural model. Concerning the criteria for structural model fit, [30] primarily model fit was seen to see if there are any abnormal variables, where all variances were significant with a value greater than zero, standard errors were well under the limit and all standardized factor loading were significant with the value ranging from 0.71 to 0.81. Our results exhibit strong empirical evidence for the good primary fit of the data. For the overall model fit for all variable, we opted indexes such as; absolute, incremental, and parsimonious, [26] whereas all the indices met the criteria, i.e. $(X 2=99.783, \mathrm{RMSEA}=0.018 ; \mathrm{GFI}=.973, \mathrm{AGFI}=$ $.962, \mathrm{NFI}=.972, \mathrm{TLI}=.996, \mathrm{CFI}=0.996 ; \mathrm{X} 2 / \mathrm{DOF}=1.147, \mathrm{p}<$ .01 ;) demonstrating an acceptable overall model fit. Lastly for aggregation analysis, IRR + IRA [28] technique was used commonly known as ICC $(K)$ for the mindful organizing scale (collective construct). According to the literature, the value of ICC (K) above 0.7 suggests considerable acceptability. [28] Our findings reported sizeable ICC (K) which justifies aggregation of data to the team level. Results of ICC (K) ranged from .91 to .93, which shows the level of agreement between respondents for mindful organizing.

\section{DISCUSSION AND CONCLUSION}

Through this study validation and reliability of the Malay version of the mindful organizing scale $(16,19)$ and safety performance scale of Neal \& Griffin (9). We translated the English version of the mindful organizing as well as safety performance scale to be utilized not only for high-reliability organizations (HROs) of Malaysia but for other less hazardous operations nature organizations that are operating in a less tiring environment. Through this research, we provided empirical evidence for the sound psychometric properties of the Malay version of the mindful organizing and safety performance scales. We achieved this by attaining internal factor structure validity, reliability of the scales, their convergent and discriminant validity alongside their association with each other. Through this research, we also provided empirical evidence to see the teams' in-between agreement on mindful organizing, 
which certifies the notion that mindful organizing is a social construct that comes into the existence through mutual efforts of the teams i.e. constitution through the actions and interactions.

Reference to the psychometric properties (the internal structure) of the mindful organizing scale, our findings are in harmony with the recent empirical evidence of mindful organizing researches in the context of occupational safety. For instance, standardized factor loadings for mindful organizing in different studies were reported as; ranged from 0.79 to 0.91 with the reliability of .95, [31] from 0.89 to 0.96 with the reliability of $0.94,[15]$ highly significant factor loading at $(P<0.001)$ with the reliability of 0.88 . [16] Whereas, some of the studies have only reported Cronbach alpha value of the unidimensional scale of mindful organizing e.g. $a=.090$, [32] $a=.093$. [20] A greater reliability score ie. Cronbach alpha value $a=0.092$ offered incremental validity for the original scale of mindful organizing. In comparison to aforesaid, all of the factor loadings for mindful organizing scale raged from 0.716 to 0.805, and for both safety compliance and safety participation, factor loading ranged from 0.746 to 0.815 with Cronbach alpha value of $a=0.813$ and $a=0.818$. An organization's ability to reap future advantages from this team-level construct is bolstered by the consistency and harmony of our findings. Our data also supported the aggregation of responses for mindful organizing at a team level, and organizations can assess the individual teams' mindfulness practice by assessing them individualy. [19] It is possible that by looking at ongoing behaviors and interactions on the unit, the mindful organizing scale might assist distinguish between safe and potential unsafe teams.

Considering that our findings are in line with previous research, this adds to the predictability of mindful organizing for safety performance. The healthcare sector may exploit mindful organizing to pursue enhanced safety objectives that can contribute towards the creation of a more safe workplace for nursing staff as well as for the patients. Health care professionals face a wide range of risks at work, including chemical, biological, radioactive, and physical threats. Consequently, not only is the safety of the healthcare workers at their workplace is crucial for them, but also for the patients they are caring for.[33] Although we have provided the empirical evidence of reliability and validity of mindful organizing scale in the healthcare sector, this is not the perennial evidence or eventual outcome, as the ability to anticipate and detect anomalies when they are weak and act swiftly to eliminate bigger consequences is not limited to the nursing staff. The phenomenon can be generalized or tested at the top-level executives and the management of hospitals to assess the organizational mindfulness to the external and everchanging environment. Further mindful organizing can further be tested with other safety-related constructs be it individual or team level to see its discriminant aspect to further exploit its fruitfulness, as the research on this construct has still not reached maturity.[34]

\section{PRACTICAL IMPLICATIONS}

Our study's outcome i.e. validation of the Malays version of mindful organizing scale has made noteworthy practical implications. The Malay language is native to more than seven countries including Malaysia, Indonesia, Brunei, Singapore, Thailand, East Timor, etc. with the language speakers of about 215 million. Keeping in view this huge amount of Malay language speakers formally and casually, our developed scale may be helpful to be utilized in Malay speaking countries and organizations to investigate the existence of mindful organizing among their teams, which has proved to be enhancing operational safety and reliability in the past. $[4,12,14,16]$ In connection with aforesaid, some self-audits for high-reliability organization principles are described by Weick and Sutcliffe [19] in their book (HROs). For example, an enterprise can start with a broad assessment of its mindfulness and go on to grouplevel mindful organizing to determine if this phenomenon is prevalent amongst its personnel. Discussing such nuances is essential to the adaptation of the Malay mindful organizing scale, which requires significant attention and thoughtful consideration when adapting this phenomenon in any organization since the cultural environment would be new to it.

Healthcare is the one sector that comes under the group of reliability-seeking organizations, [15] where the Malay version of the mindful organizing scale would a valuable tool for an organization to measure mindful organizing in their teams to anticipate, detect and mitigate the forthcoming issues. Our developed scale is not only limited to be utilized in healthcare setup, but it can be utilized (after the initial self-assessments proposed earlier) in an actual high-reliability organization (HRO) i.e. Nuclear power plants, aviation, air transport controlling units, and oil and gas operations throughout the region wherever the Malay language is spoken read, or written. Managers of hospitals can use this translated version of the mindful organizing scale to evaluate their nursing teams' collective ability in terms of error anticipation as well as recovering from them, 
which ultimately will enhance their safety performance (patient safety, reduced medication error, better healthcare, etc.). Our translated version is also of reasonable length which also helps respondents to provide their response with ease and minimize the risk of any bias or reading fatigue. Since the mindful organizing scale helps to identify the prevalence of mindfulness amongst team members, thus managers can utilize this construct not only for safety improvements but for general performance improvements as well. Organizations can also observe through this social construct the nature of social interaction amongst their team, as to how much they are heedful and cohesive when performing tasks in the group (35). Mindful organizing also relies upon the respectful interaction of employees as it helps them involve in mindful organizing, [17] thus opting for mindful organizing may yield interesting insights about this social interaction aspect amongst employees. Mindful organizing is the higher-order construct that emerged from the principles of high-reliability organization (HROs), that can be distinctively and separately measured. [19] It's all sub-dimensions (if measured separately) i.e. preoccupation with failure, sensitivity to information, reluctance to simplify, commitment to resilience, and deference to the expertise can provide a vivid and clear picture about the social interaction of employees, thus leading to a better understanding and operational control of the organization as well as manager. Healthcare managers may discover training needs for their employees by using a mindful organizing scale, as well as evaluate which aspects are lacking in order to improve safety performance.

\section{STUDY LIMITATIONS}

The fact that every study has some limitations is undeniable. Using cross-sectional data, which is time-dependent, as opposed to longitudinal research covering many periods of time, is one of the study's first drawbacks. As a result of prior research that has tested mindful organizing in highreliability organizations (HROs) over several time periods, a future longitudinal study in the healthcare setting will be necessary. Usually, it has been found that respondents' responses to a self-reported instrument influenced how honest they were while responding to the survey.[36] As all of our respondents were from private hospitals, and normally, in healthcare occupational settings, personal as well as patient safety is the prime concern, participants may have fallen to "social desirability bias" and exaggerated their levels of mindful organizing, which is especially important in this case. This bias has also been highlighted in the past concerning mindful organizing.[37] In addition, our findings are applicable to the Malaysian cultural setting, which will need to be validated worldwide in the future. The nurses who responded to our survey are directly involved in the provision of healthcare in different teams primarily performing on an operative level, but in the future, the participation of higher hierarchy and top management from the healthcare industry might offer fascinating insights. Lastly, through this study, we have only attained the evidence of validity and reliability between three distinct variables one at team-level (mindful organizing) and two at an individual level (safety compliance and safety performance) but couldn't attain the path or nomological evidence by assessing the predicting and outcome role. This urges the needs of future study to test mindful organizing and safety performance in an antecedent and outcome form to validate their further nomological structure.

\section{References}

1. US Bureau of Labor Statistics. 2017 SURVEY OF OCCUPATIONAL INJURIES \& ILLNESSES CHARTS PACKAGE. U.S. Department of Labor; 2018.

2. OSHA. Healthcare - Overview | Occupational Safety and Health Administration [Internet]. 2021 [cited 2021 Jun 8]. Available from: https://www.osha.gov/healthcare

3. SOCIAL SECURITY ORGANIZATION. LAPORAN TAHUNAN_ANNUAL REPORT 2018 [Internet]. 2018. Available from:

https://www.perkeso.gov.my/en/about-us/mediacentre/annual-report.html

4. Weick, Sutcliffe KM, Obstfeld, D. Organizing for High Reliability: Processes of Collective Mindfulness. JAI Press; 1999. book.

5. Vogus TJ, Sutcliffe KM. Organizational Mindfulness and Mindful Organizing: A Reconciliation and Path Forward. 2012;15.

6. Weick KE, Sutcliffe KM. Mindfulness and the Quality of Organizational Attention. Organ Sci. 2006;12.

7. Griffin MA, Neal A. Perceptions of Safety at Work: A Framework for Linking Safety Climate to Safety Performance, Knowledge, and Motivation. J Occup Health Psychol. 2000;05(03):347-58. 
8. Burke MJ, Dunlap WP. Estimating Interrater Agreement with the Average Deviation Index: A User's Guide.

Organ Res Methods. 2002 Apr;5(2):159-72.

9. Neal A, Griffin MA. A study of the lagged relationships among safety climate, safety motivation, safety behavior, and accidents at the individual and group levels. J Appl Psychol. 2006;91 (4):946-53.

10. Morris RL, Ruddock A, Gallacher K, Rolfe C, Giles S, Campbell $S$. Developing a patient safety guide for primary care: A co-design approach involving patients, carers and clinicians. Health Expect. 2021 Feb;24(1):42-52.

11. Sutcliffe KM, Vogus TJ, Dane E. Mindfulness in Organizations: A Cross-Level Review. Annu Rev Organ Psychol Organ Behav. 2016 Mar 21;3(1):55-81.

12. Ausserhofer $D$, Schubert $M$, Desmedt $M$, Blegen MA, De Geest S, Schwendimann R. The association of patient safety climate and nurse-related organizational factors with selected patient outcomes: A cross-sectional survey. Int J Nurs Stud. 2013 Feb;50(2):240-52.

13. Vogus TJ, Sutcliffe KM. The Impact of Safety Organizing, Trusted Leadership, and Care Pathways on Reported Medication Errors in Hospital Nursing Units. Med Care. 2007;45(10):6.

14. Bigley GA, Roberts KH. The Incident Command System: High-Reliability Organizing for Complex and Volatile Task Environments. Acad Manage J. 2001 Dec $1 ; 44(6): 1281-99$.

15. Tomás I, Gracia FJ, Peiró JM. Spanish validation of the mindful organizing scale: A questionnaire for the assessment of collective mindfulness. Accid Anal Prev. 2020 Jan; 134:105351.

16. Vogus TJ, Sutcliffe KM. The Safety Organizing Scale: Development and Validation of a Behavioral Measure of Safety Culture in Hospital Nursing Units. Med Care. 2007 Jan;45(1):46-54.

17. Vogus TJ, lacobucci D. Creating Highly Reliable Health Care: How Reliability-Enhancing Work Practices Affect Patient Safety in Hospitals. ILR Rev. 2016 Aug;69(4):911-38.

18. Zaheer S, Ginsburg L, Wong HJ, Thomson K, Bain L, Wulffhart Z. Turnover intention of hospital staff in Ontario, Canada: exploring the role of frontline supervisors, teamwork, and mindful organizing. Hum Resour Health. 2019 Dec;17(1):66.
19. Weick KE, Sutcliffe KM. Managing the Unexpected Resilient Performance in an Age of Uncertainty by Karl E. Weick, Kathleen M. Sutcliffe (z-lib.org).pdf. 2nd ed. 2007.

20. Gracia FJ, Tomás I, Martínez-Córcoles M, Peiró JM. Empowering leadership, mindful organizing and safety performance in a nuclear power plant: A multilevel structural equation model. Saf Sci. 2020 Mar;123:104542.

21. Wild D, Grove A, Martin M, Eremenco S, McElroy S, Verjee-Lorenz A, et al. Principles of Good Practice for the Translation and Cultural Adaptation Process for Patient-Reported Outcomes (PRO) Measures: Report of the ISPOR Task Force for Translation and Cultural Adaptation. Value Health. 2005 Mar;8(2):94-104.

22. Kozlowski SWJ, Bell BS. Work groups and teams in organizations. In: Handbook of psychology: Industrial and organizational psychology, Vol 12. Hoboken, NJ, US: John Wiley \& Sons Inc; 2003. p. 333-75.

23. Naji GMA, Isha ASN, Mohyaldinn ME, Leka S, Saleem MS, Rahman SMNBSA, et al. Impact of Safety Culture on Safety Performance; Mediating Role of Psychosocial Hazard: An Integrated Modelling Approach. Int J Environ Res Public Health. 2021 Aug $13 ; 18(16): 8568$.

24. Naji GMA, Isha ASN, Alzoraiki M, Al-Mekhlafi A-BA, Sharafaddin O, Saleem MS. Impact Of Safety Culture And Psychosocial Hazard On Safety Performance Among Upstream Employees In Malaysia At Oil And Gas Industry. Solid State Technol. 2020 Oct 27;63(6):4120-6.

25. Naji GMA, Isha AN, Bin SMN, Rahman SA, Alzoraiki $M$, Al-Mekhlafi A-B, et al. The Role of HR Strategy on Safety Culture and Psychological Stress among Employees in the Upstream Oil and Gas Companies: a Conceptual Review. Solid State Technol. 2020;63(5):12.

26. Fang D, Wu C, Wu H. Impact of the Supervisor on Worker Safety Behavior in Construction Projects. J Manag Eng. 2015 Nov;31 (6):04015001.

27. Hu L, Bentler PM. Cutoff criteria for fit indexes in covariance structure analysis: Conventional criteria versus new alternatives. Struct Equ Model Multidiscip J. 1999 Jan;6(1):1-55.

28. LeBreton JM, Senter JL. Answers to 20 Questions About Interrater Reliability and Interrater Agreement. Organ Res Methods. 2008 Oct; 11 (4):815-52. 
29. Nunnally JC. An Overview of Psychological

Measurement. In: Wolman BB, editor. Clinical

Diagnosis of Mental Disorders [Internet]. Boston, MA:

Springer US; 1978 [cited 2021 Apr 3]. p. 97-146.

Available from: http://link.springer.com/10.1007/978-1-

4684-2490-4_4

30. Bagozzi RR, Yi Y. On the evaluation of structural equation models. 1988;21.

31. Renecle M, Gracia FJ, Tomas I, Peiró JM. Developing Mindful Organizing in Teams: A Participation Climate is not Enough, Teams Need to Feel Safe to Challenge their Leaders. Rev Psicol Trab Las Organ. 2020 Nov 13;36(3):181-93.

32. Renecle M, Curcuruto M, Gracia Lerín FJ, Tomás Marco I. Enhancing safety in high-risk operations: A multilevel analysis of the role of mindful organising in translating safety climate into individual safety behaviours. Saf Sci. 2021 Jun;138:105197.

33. Hughes RG, editor. Patient Safety and Quality: An Evidence-Based Handbook for Nurses [Internet]. Rockville (MD): Agency for Healthcare Research and Quality (US); 2008 [cited 2021 Aug 9]. (Advances in Patient Safety). Available from: http://www.ncbi.nlm.nih.gov/books/NBK2651/

34. Martínez-Córcoles M, Vogus TJ. Mindful organizing for safety. Saf Sci. 2020 Apr;124:104614.

35. Weick KE, Roberts KH. Collective Mind in Organizations: Heedful Interrelating on Flight Decks. Adm Sci Q. 1993;38(3):357-81.

36. Paulhus DL. Socially Desirable Responding: The Evolution of a Construct. In: The Role of Constructs in Psychological and Educational Measurement [Internet]. 0 ed. Routledge; 2002 [cited 2021 Apr 2]. p. 61-84. Available from: https://www.taylorfrancis.com/books/9781 135649906/ chapters/10.4324/9781410607454-10

37. Saleem MS, Isha ASN, Mohd Yusop Y, Awan MI, Naji GMA. Agility and Safety Performance among Nurses: The Mediating Role of Mindful Organizing. Nurs Rep. 2021 Aug 30;1 1 (3):666-79. 


\section{ENGLISH AND MALAY VERSION OF MINDFUL ORGANIZING AND SAFETY BEHAVIOR SCALES}

\section{MINDFUL ORGANIZING SCALE}

"Apabila membincangkan masalah yang timbul dengan rakan sekerja, kebiasaannya kami membincangkan perkara yang perlu diperhatikan".

"When discussing emerging problems with co-workers we normally discuss what to look out for".

"Kami meluangkan masa untuk mengenal pasti aktiviti yang kami tidak mahu salah".

"We spend time identifying activities we do not want to go wrong".

"Kami membincangkan alternatif bagaimana untuk menjalani aktiviti kerja normal kami".

"We discuss alternatives as to how to go about our normal work activities".

"Kami mempunyai tanggapan yang baik bagi setiap bakat dan kemahiran individu".

"We have a good map of each person's talents and skills".

"Kami membincangkan kemahiran unik kami di antara satu sama lain supaya kami mengetahui siapa yang mempunyai kemahiran khusus dan pengetahuan yang relevan".

"We discuss our unique skills with each other so that we know who has relevant specialized skills and knowledge".

"Kami bercakap tentang kesalahan dan cara-cara untuk belajar darinya".

"We talk about mistakes and ways to learn from them".

"Apabila berlakunya kesalahan, kami bincangkan bagaimana kami dapat mencegahnya".

"When errors happen, we discuss how we could have prevented them".

"Apabila mencuba untuk menyelesaikan masalah, kami memanfaatkan kemahiran unik rakan sekerja kami'.

"When attempting to solve a problem, we take advantage of the unique skills of our colleagues".

"Apabila krisis berlaku, kami segera mengumpulkan kepakaran kami untuk cuba menyelesaikannya".

"When a crisis occurs we rapidly pool our collective expertise to attempt to resolve it".

\section{SAFETY BEHAVIOR SCALE}

"Saya menggunakan semua peralatan keselamatan yang diperlukan untuk melaksanakan tugasan saya".

"I use all the necessary safety equipment to do my job".

"Saya menggunakan prosedur keselamatan yang betul untuk menjalankan tugas on saya".

"I use the correct safety procedures for carrying out my job".

"Saya memastikan tahap keselamatan tertinggi semasa menjalankan tugas".

"I ensure the highest levels of safety when I carry out my job".

"Saya mempromosikan program keselamatan di dalam organisasi".

"I promote the safety program within the organization".

"Saya berusaha sedaya upaya untuk meningkatkan keselamatan di tempat kerja".

"I put in extra effort to improve the safety of the workplace".

"Saya secara sukarela menjalankan kerja-kerja atau aktiviti yang membantu meningkatkan keselamatan di tempat kerja".

"I voluntarily carry out tasks or activities that help to improve workplace safety". 